\title{
Solar Atlas of New Zealand from satellite imagery
}

\author{
Alan C. Brent, James (Jim) Hinkley, Daniel Burmester \& Ramesh Rayudu
}

To cite this article: Alan C. Brent, James (Jim) Hinkley, Daniel Burmester \& Ramesh Rayudu (2020): Solar Atlas of New Zealand from satellite imagery, Journal of the Royal Society of New Zealand, DOI: 10.1080/03036758.2020.1763409

To link to this article: https://doi.org/10.1080/03036758.2020.1763409

+ View supplementary material $\widetilde{ }$

曲 Published online: 25 May 2020.

Submit your article to this journal $[\pi$

Џ Article views: 12

Q View related articles $₫$

View Crossmark data $\asymp$ 


\title{
Solar Atlas of New Zealand from satellite imagery
}

\author{
Alan C. Brent (D), James (Jim) Hinkley (D), Daniel Burmester (i) and Ramesh Rayudu \\ Sustainable Energy Systems, School of Engineering and Computer Science, Victoria University of Wellington, \\ New Zealand
}

\begin{abstract}
The utilisation of solar resources has become of utmost importance for the transition of the global, carbon intensive economy. In New Zealand the uptake of solar energy has increased substantially, but the relative contribution to the overall energy mix is still small. Previous research efforts on the solar resource across the country are revisited with improved satellite-modelled data from Solargis to derive a solar atlas for the country. A comparison is made with NIWA data, which shows that the modelled data are at an adequate level of accuracy and improves our understanding of the solar resource at an appropriate spatial and temporal resolution. The solar atlas makes available a commercial satellite data source and informs further investigations into how solar can, and will, play a more meaningful role in our transition to a low carbon future.
\end{abstract}

\section{ARTICLE HISTORY}

Received 15 January 2020

Accepted 28 April 2020

\section{KEYWORDS}

Renewable energy; solar resource; solar energy; solar technology; New Zealand

\section{Introduction}

The Key World Energy Statistics of the International Energy Agency (IEA 2018) shows that renewable energy resources, other than biofuels and waste, contribute only $5 \%$ when considering the total primary energy supply (TPES). This is a key concern for decarbonising the world economy. However, while the TPES is stabilising towards 585,000 PJ globally, and around 221,900 PJ in OECD countries, the contribution of renewables is becoming more important, with hydro electricity production increasing by around three times (to over 21,000 PJ), wind electricity production by a factor of ten (to around 5,000 PJ), and solar by nearly one hundred times (to over 1,700 PJ), from 2005 to 2016. With respect to solar photovoltaic (PV) technologies, the International Renewable Energy Agency (IRENA 2019) indicates a 64\% increase in installed capacity from 2016 to 2018, to over $480 \mathrm{GW}$ (from $100 \mathrm{GW}$ in 2012). The IEA (2019) projects this capacity to increase to around $700 \mathrm{GW}$ in 2024 , with around half of the installed capacity attributable to distributed PV (as opposed to centralised, utility-scale installations).

New Zealand has also seen a growth in the uptake of solar PV, with the installed capacity increasing by $26 \%$ for the year ending in September 2019, to over $100 \mathrm{MW}$ (EA 2019). The largest increase has been in the Auckland and Canterbury regions, attributable to the perceived solar resource and the market size in these regional councils (see Figure 1). Nevertheless, the Ministry of Business, Innovation and Employment (MBIE

CONTACT Alan C. Brent alan.brent@vuw.ac.nz ( https://www.wgtn.ac.nz/sustainable-energy-systems 


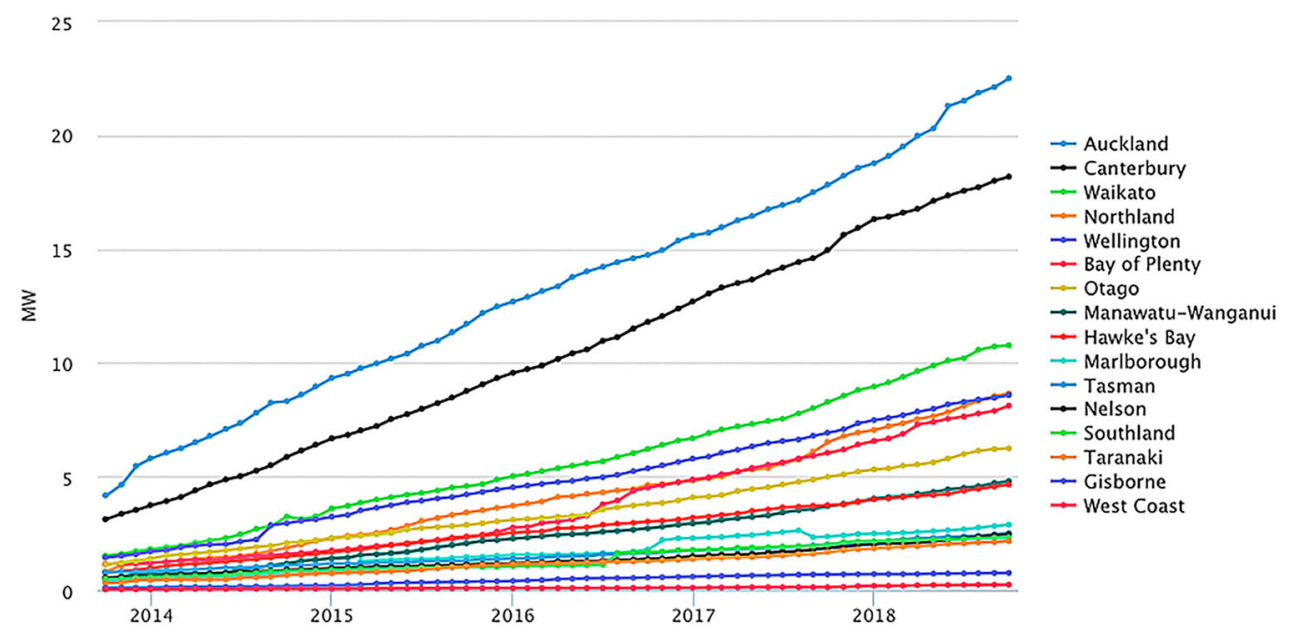

Figure 1. Installed solar PV distributed generation trends in New Zealand. Source: emi.ea.govt.nz.

2019) reports that, in 2018, the energy from solar PV constituted less than $0.1 \%$ (or 0.72 PJ) of the TPES in the economy (890.68 PJ). On the other hand, an addendum to the Te Mauri Hiko scenarios of Transpower (2019) projects solar to generate between 36 and 115 PJ of electricity (of a total of 317 PJ) by 2050, of which at least half will be from distributed solar PV.

The question is then whether solar energy will see sustained growth in New Zealand, and to what extent this resource can contribute to a just transition to a net zero carbon emissions economy, as envisaged through the Climate Change Response (Zero Carbon) Amendment Act (Parliamentary Counsel Office 2019). The first step to address the question is to have a good understanding of the solar resource across the country, at an appropriate spatial and temporal resolution, and then investigate how the resource relates to the energy demand profiles in the economy.

\section{Previous and ongoing analyses of the solar resource}

Research up to 2010, on the potential to transition the electricity system of New Zealand to $100 \%$ renewables, largely ignored the potential of solar, on the basis that the resource is limited and the nascent state of development of the conversion technologies at the time (Mason et al. 2010). Nevertheless, early estimates of the solar radiation in New Zealand were made for specific locations (Western 1990; Anderson and Duke 2007), and mean annual solar radiation data were captured in the Land Resource Information Systems (LRIS) portal in 2010 (Landcare Research 2010), as part of the Land Environments of New Zealand (LENZ) programme of the Ministry for the Environment (Leathwick et al. 2002). Surface estimates of monthly and annual solar radiation were fitted in a geographical information system (GIS) layer using climate data from a total of 98 meteorological stations for which solar radiation data were either measured directly (18) or estimated from sunshine hours. Many subsequent research efforts have relied on this data (see Table 1), which is maintained in the National Climate Database and provided through the CliFlo web system of the National Institute of Water and Atmospheric 
Table 1. An overview of previous New Zealand studies and sources of data used.

\begin{tabular}{ll}
\hline Study & Data source \\
\hline Western 1990 & Measurements take at a specific location and calibrated with meteorological station data \\
Anderson and Duke 2007 & Meteorological station data \\
Landcare Research 2010 & Estimates/predictions from 98 meteorological stations \\
Eltayeb 2013 & NIWA/LENZ maps \\
Liley 2013 & NIWA Climate Database and the effect of clouds from twice-daily AVHRR satellite \\
& overpass \\
Ahmad et al. 2015 & CliFlo database - 2014 \\
Hyett 2017 & Physical measurements at the Lauder meteorological station \\
Suomalainen et al. (2017a, & LiDAR data, and the Solar Radiation toolkit of the ArcGIS software* to cover an area of \\
2017b) & 2250 km \\
\hline
\end{tabular}

*http://desktop.arcgis.com/en/arcmap/10.3/tools/spatial-analyst-toolbox/an-overview-of-the-solar-radiation-tools.htm

Research (NIWA 2019a). The database collects data from over 600 monitoring stations that are currently operating, and CliFlo returns raw data and statistical summaries.

Further research efforts have provided a better estimation of the solar radiation for the whole country, based on the monitoring stations' data and adjusted for the effects of clouds, using, for example, the twice daily overpass of advanced very-high resolution radiometer (AVHRR) instruments on satellites (Liley 2013). The analysis approach is the basis for the SolarView program and calculation tool of NIWA (2019b), which is meant to be a guide, and not for accurate predictions (NIWA 2019c). The program combines an image of the local landscape with irradiance data averaged over ten years, typically sunlight hours data, from the nearest climate station to a specified location, on an hourly basis.

The national monitoring and analyses are ongoing (for example Hyett 2017) as part of the Baseline Surface Radiation Network (BSRN) of the World Climate Research Programme (WCRP 2018).

A more in-depth analysis of the solar resource, and the potential for solar PV, was undertaken for the Auckland metropolitan area. The Energy Centre of the University of Auckland established a web-based tool to evaluate the rooftop solar potential in Auckland (Suomalainen et al. 2017a, 2017b). A digital 3D model of the city was developed with its topography, trees and buildings, to calculate the slope and aspect of Auckland rooftops, and the associated annual solar radiation, from $\operatorname{LiDAR}^{1}$ data provided by the Auckland Council, at a spatial resolution of one square metre. The results show an underestimation of between 5 and 10\%, when compared to the SolarView tool of NIWA. The difference may be attributable to spatial resolution when analysing the solar resource, but no conclusive argument is made (Suomalainen et al. 2017a, 2017b) due to the inherent uncertainties with the output of the SolarView tool (NIWA 2019c).

\section{Advances in solar radiation modelling and remote sensing}

Modelling solar irradiance from satellite imagery has become the most widely used approach for evaluating solar resources (Kaskaoutis and Polo 2019), with two key applications (Bright 2019):

- Solar irradiance forecasting, which is vital for power systems management, where the capability to proactively manage the intermittent solar resource is imperative for reliable and secure operations of the grid. 
- Production of historical irradiance datasets for solar resource assessment and yield analysis of solar facilities.

The common temporal resolution, or standard image frequency, is $30 \mathrm{~min}$, which, importantly, corresponds with the New Zealand electricity market (Philpott et al. 2019).

The principles and methods for estimating the solar resource from satellite imagery are well established (Bright 2019; Polo and Perez 2019), and satellite-based models are divided into: models using polar orbiting satellite imagery, and models for geostationary satellites. However, with respect to the available remote sensing technologies, geostationary satellite images provide unrivalled temporal and spatial resolutions (Bright 2019). The spatial resolution is now provided in the order of hundreds of metres, which is adequate to, for example, evaluate rooftop solar PV performances across countries (Bódis et al. 2019).

\section{Establishing a Solar Atlas of New Zealand}

Many commercial solar radiation products and databases that were, and are, developed from satellite imagery, are available (Polo and Perez 2019). The World Bank Group, with funding from the Energy Sector Management Assistance Programme (ESMAP) selected Solargis, a widely used service provider, to establish the Global Solar Atlas (Solargis 2019a).

Based on this platform Victoria University of Wellington undertook the development of a Solar Atlas of New Zealand with Solargis (2019b). The solar radiation was calculated by numerical models, which are parameterised by a set of inputs characterising the cloud transmittance, state of the atmosphere, and terrain conditions (Solargis 2019b).

Perez et al. (2013) provide a comprehensive overview of the Solargis models, and Cebecauer et al. (2010) and Súri et al. (2010) describe the underlying methodologies. Cebecauer et al. (2011) and Š́ri and Cebecauer (2014) discuss the related uncertainty and requirements for bankable datasets.

The full technical report of Solargis (2019b) contains the further details that underpin the developed Solar Atlas, and is provided as supplementary material to this paper. Table 2 provides an overview of the input data used in the models and the related solar resource outputs - as Global Horizontal Irradiance (GHI) and Direct Normal Irradiance (DNI).

Table 2. Input data used in the Solargis solar radiation model and the related GHI and DNI outputs.

\begin{tabular}{|c|c|c|c|c|}
\hline Input data & Source & $\begin{array}{c}\text { Time } \\
\text { representation }\end{array}$ & Original time step & $\begin{array}{l}\text { Approximate grid } \\
\text { resolution }\end{array}$ \\
\hline \multirow[t]{2}{*}{ Cloud index } & MTSAT 2 satellite & 07/2006-2015 & $30 \mathrm{~min}$ & $4.6 \times 7.1 \mathrm{~km}$ \\
\hline & $\begin{array}{l}\text { Himawari } 8 \text { satellite } \\
\text { (both JMA) }\end{array}$ & 2016 to date & $10 \mathrm{~min}$ & $2.3 \times 3.6 \mathrm{~km}$ \\
\hline $\begin{array}{l}\text { Atmospheric optical depth } \\
\text { (aerosols)* }\end{array}$ & $\begin{array}{l}\text { MACC-II/CAMS* } \\
\text { (ECMWF) }\end{array}$ & 2007 to date & $\begin{array}{l}3 \mathrm{~h} \text { (aggregated to } \\
\text { daily) }\end{array}$ & 75 and $125 \mathrm{~km}$ \\
\hline Water vapour & CFSR/GFS (NOAA) & $01 / 2006$ to date & $\begin{array}{l}1 \mathrm{~h} \text { (aggregated to } \\
\text { daily) }\end{array}$ & 35 and $55 \mathrm{~km}$ \\
\hline Elevation and horizon & SRTM-3 (SRTM) & & & $250 \mathrm{~m}$ \\
\hline GHI and DNI & Modelled by Solargis & 2006 to date & $30 \mathrm{~min}$ & $250 \mathrm{~m}$ \\
\hline
\end{tabular}

*Aerosol data for 2007-2012 come from the reanalysis database; the data representing years 2013-present are derived from near-real time (NRT) operational model.

Source: Solargis (2019b). 
The uncertainty of the solar resource is estimated to be \pm 4.0 to $\pm 5.5 \%$ (for GHI) and \pm 9.0 to $\pm 13.0 \%$ (for DNI) (Solargis 2019b).

The Solar Atlas was derived from the Solargis algorithms using the original 10-minute and 30-minute time series of satellite images, and auxiliary atmospheric datasets; as GIS raster data layers, which, apart from the GHI $\left(\mathrm{kWh} / \mathrm{m}^{2}\right)$ and DNI $\left(\mathrm{kWh} / \mathrm{m}^{2}\right)$, comprise of: GTI - Global Tilted Irradiation at optimum angle $\left(\mathrm{kWh} / \mathrm{m}^{2}\right)$, DIF - Diffuse horizontal irradiation $\left(\mathrm{kWh} / \mathrm{m}^{2}\right)$, OPTA - Optimum Angle for GTI $\left(^{\circ}\right)$, TEMP - Temperature at 2 metres $\left({ }^{\circ} \mathrm{C}\right)$, and PVOUT - Photovoltaic Electricity Output $(\mathrm{kWh} / \mathrm{kWp})$. Images of the long-term average GIS raster data layers are provided for monthly and yearly GHI totals as further supplementary material to this paper (see, for example, Figures 2 and 3), which also include the transmission grid as an overlayer.

\section{Verification of the Solar Atlas with NIWA data}

The modelled data from the Solar Atlas were verified with the measured data from the meteorological station of NIWA in Kelburn, Wellington, where eighteen years of solar data have been recorded. The hourly solar data for the Kelburn station was obtained from the CliFlo database (NIWA 2019a) for the 2018 year. As per the report of the Energy Sector Management Assistance Programme (ESMAP 2019), twelve months of data is deemed adequate to validate the modelling outputs.

The measurement data were assumed to be of high quality, with acceptable errors from well-maintained instruments. However, at certain times over the year, especially from September to November, the measurement equipment were not operational. These data points were excluded from the dataset, which comprises of 4,335 $\mathrm{h}$ when the solar resource was measured by NIWA and modelled by Solargis.

Table 3 provides the cumulative GHI on a monthly and annual basis. The difference between the cumulative, annual measured and modelled data is less than $42.5 \mathrm{kWh} / \mathrm{m}^{2}$. The statistical parameter that is commonly used for evaluation of differences between satellite data and ground measurements (ESMAP 2019) is the relative Mean Bias Deviation (rMBD), and is calculated to be $3.2 \%$ for the annual GHI data. This is similar to the $\pm 3.1 \%$ bias reported for $80 \%$ of 208 site validations across the globe, and the $\pm 4 \%$ reported for the Lauder measurement site in New Zealand (Solargis 2019c).

For the summer months (December, January and February) the rMBD is $0.6 \%$, but for the winter months (June, July and August) the rMBD is $8.3 \%$. This emphasises the importance of the clouds, for example intermediate clouds, when analysing a specific site. For locations with high levels of cloud persistence and variability, the report of ESMAP (2019) indicates a P90 uncertainty estimate of $\pm 7 \%$. For New Zealand, the modelling output (in Table 3) indicates a clear underestimation of cloud effects, although the actual overestimation of the GHI values is deemed small; for example, if the values are used to analyse monthly solar PV outputs.

In terms of the daily solar resource profile, the maximum GHI was recorded at $13 \mathrm{~h} 00$ on the 6 th of January, with $1.108 \mathrm{kWh} / \mathrm{m}^{2}$. The minimum GHI at $13 \mathrm{~h} 00$ was recorded on the 1 st of July, with $0.039 \mathrm{kWh} / \mathrm{m}^{2}$. A comparison of the Solar Atlas analysis with the hourly recorded data, for these two days, are provided in Figures 4 and 5.

For days with a better solar resource, the Solar Atlas provides a similar daily profile, although (for this case) with a lower cumulative GHI; $6.285 \mathrm{kWh} / \mathrm{m}^{2}$ compared to 


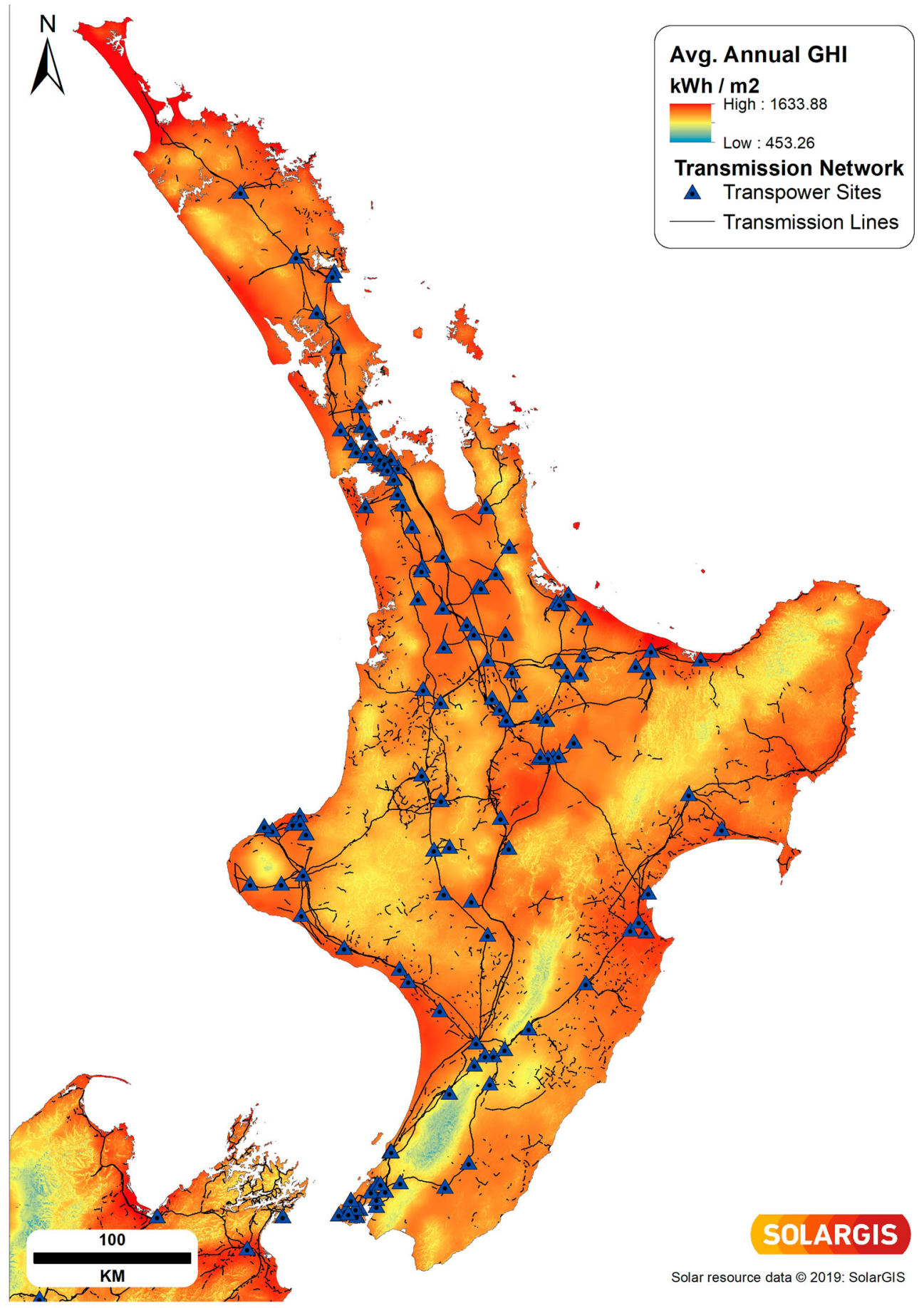

Figure 2. Long-term average of annual sum of $\mathrm{GHI}$, period $2007-2018\left[\mathrm{kWh} / \mathrm{m}^{2}\right]$, for the North Island. Source: Compiled from Solargis (2019b) and Transpower (2018). 


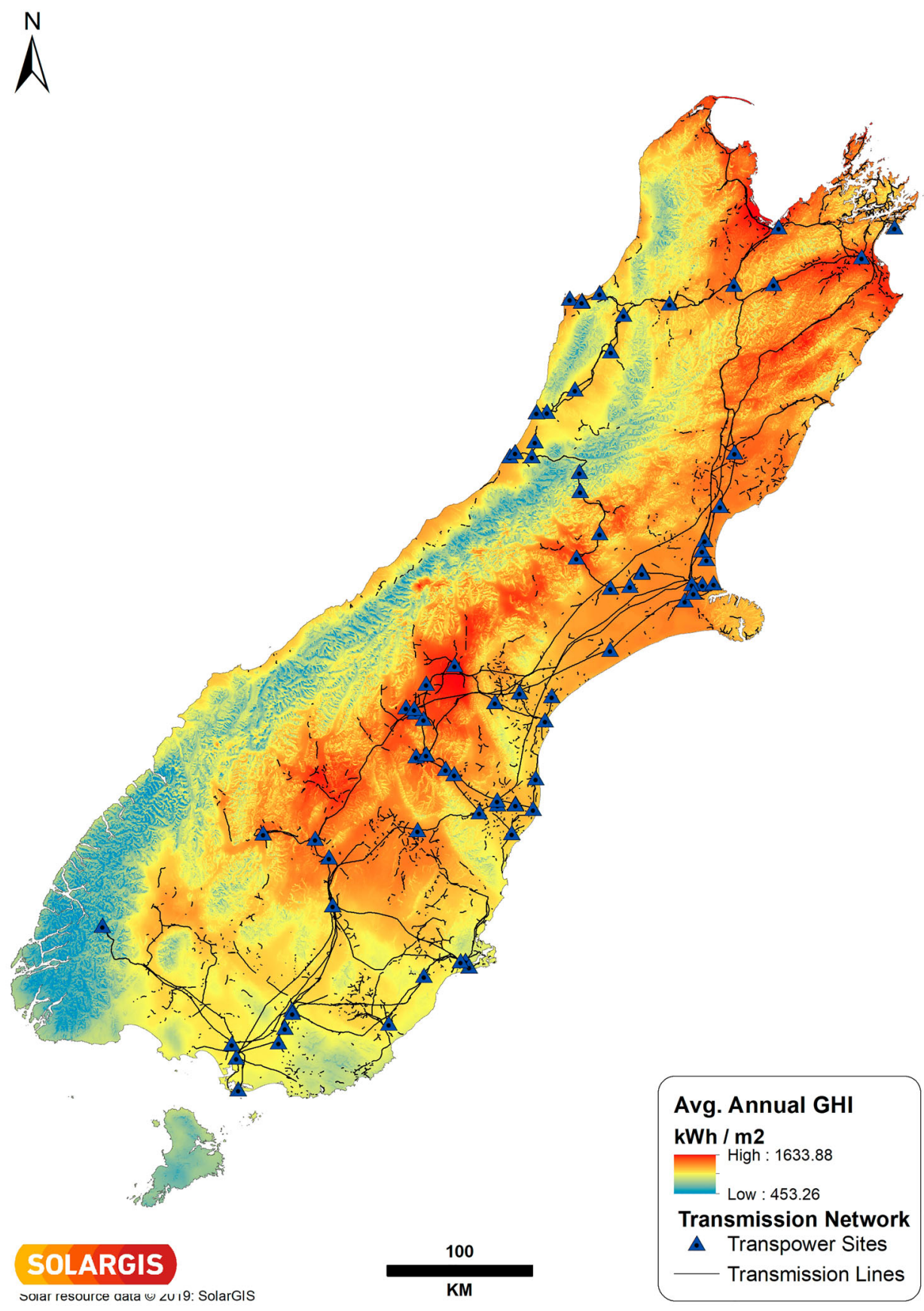

Figure 3. Long-term average of annual sum of $\mathrm{GHI}$, period $2007-2018\left[\mathrm{kWh} / \mathrm{m}^{2}\right]$, for the South Island. Source: Compiled from Solargis (2019b) and Transpower (2018).

$6.481 \mathrm{kWh} / \mathrm{m}^{2}$ from the actual measurements on the 6 th of January, or a rMBD of $-3.1 \%$. For days with a worse solar resource, the results are significantly different in two ways. First, the cumulative GHI from the Solar Atlas can be much different; $0.665 \mathrm{kWh} / \mathrm{m}^{2}$ 
Table 3. Comparison of the CliFlo data and the Solar Atlas outputs for the average monthly GHI resource - for 2018.

\begin{tabular}{|c|c|c|c|c|}
\hline Month & $\begin{array}{c}\text { CliFlo } \\
\mathrm{kWh} / \mathrm{m}^{2}\end{array}$ & $\begin{array}{l}\text { Solar Atlas } \\
\mathrm{kWh} / \mathrm{m}^{2}\end{array}$ & $\begin{array}{c}\text { Difference } \\
\mathrm{kWh} / \mathrm{m}^{2}\end{array}$ & $\begin{array}{c}\mathrm{rMBD}^{*} \\
\%\end{array}$ \\
\hline January & 189.6 & 188.6 & -0.9 & -0.5 \\
\hline February & 151.9 & 151.3 & -0.6 & -0.4 \\
\hline March & 117.8 & 120.0 & 2.2 & 1.9 \\
\hline April & 90.6 & 91.8 & 1.2 & 1.3 \\
\hline May & 54.8 & 57.4 & 2.6 & 4.5 \\
\hline June & 37.8 & 43.8 & 6.0 & 13.8 \\
\hline July & 47.9 & 51.7 & 3.8 & 7.4 \\
\hline August & 68.3 & 72.5 & 4.2 & 5.8 \\
\hline September & 94.5 & 101.6 & 7.1 & 7.0 \\
\hline October & 80.5 & 84.6 & 4.1 & 4.9 \\
\hline November & 150.3 & 158.6 & 8.2 & 5.2 \\
\hline December & 185.8 & 190.3 & 4.5 & 2.4 \\
\hline Annual & 1269.7 & 1312.1 & 42.4 & 3.2 \\
\hline
\end{tabular}

${ }^{*} \mathrm{rMBD}=1-[$ CliFlo]/[Solar Atlas].

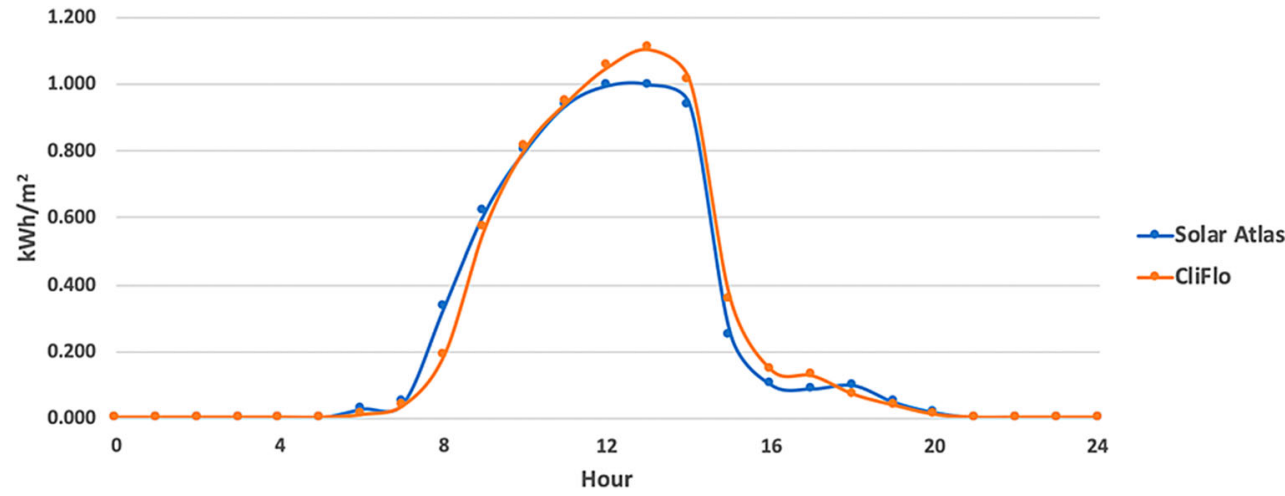

Figure 4. Recorded and modelled GHI data for the Kelburn station, on 6 January 2018.

compared to the recorded $0.386 \mathrm{kWh} / \mathrm{m}^{2}$ on the 1 st of July, or a rMBD of $41.9 \%$. Second, there can be a clear difference in the daily profile. This is (again) due to cloud effects that are not captured accurately in the modelled data from satellite imagery.

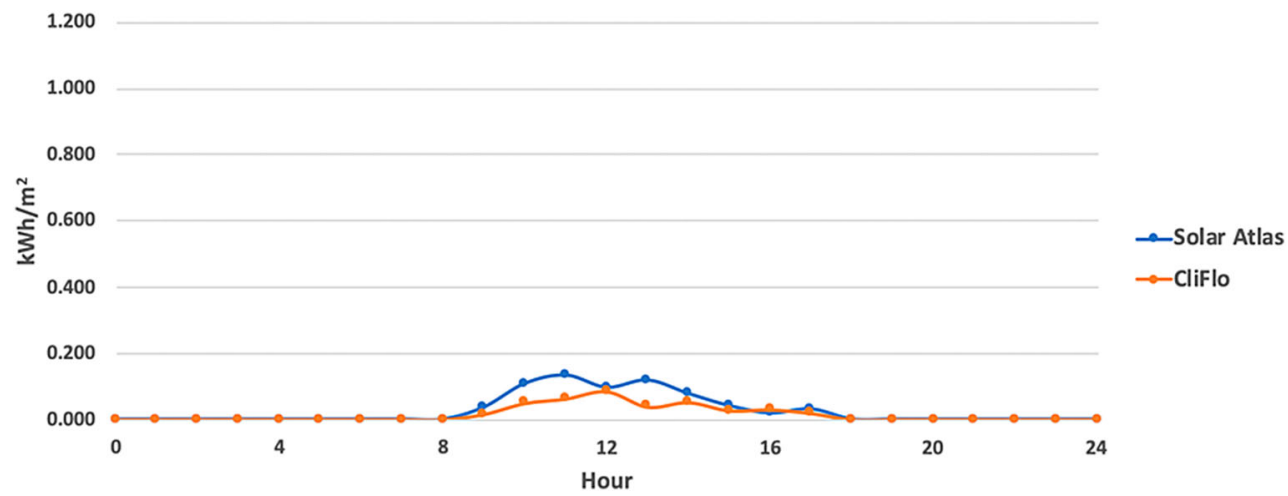

Figure 5. Recorded and modelled GHI data for the Kelburn station, on 1 July 2018. 
Table 4. Solar Atlas outputs for the average annual GHI resource at eleven hydropower sites.

\begin{tabular}{lr}
\hline Location & $\begin{array}{c}\text { Solar Atlas } \\
\mathrm{kWh} / \mathrm{m}^{2}\end{array}$ \\
\hline Lake Arapuni & 1403.7 \\
Maraetai Dam & 1378.6 \\
Lake Taupo & 1478.0 \\
Lake Tekapo & 1503.2 \\
Lake Pukaki & 1425.2 \\
Lake Benmore & 1425.1 \\
Lake Aviemore & 1418.7 \\
Clyde Dam & 1375.4 \\
Roxburgh Dam & 1239.4 \\
Lake Onslow & 1261.4 \\
Lake Manapouri & 972.9 \\
\hline
\end{tabular}

\section{Utilising the Solar Atlas}

The comparative analyses emphasise the usefulness of the Solar Atlas. It cannot replace on-site measurements, which is the industry standard and necessary for project financing. For example, for utility-scale PV projects, such as the solar farm of Refining NZ (2019) or the floating PV array at Watercare in Auckland (Maisch 2019), satellite data sources are acceptable where extensive historical data are not available, but measurements from ground-based stations are still required over a number of years to make such projects bankable (IFC 2015). It does, however, provide reasonably accurate data - typically only available commercially - to analyse the potential impact of spatially distributed solar technologies on the electricity market, and augments the SolarView tool of NIWA, which, as stated, is meant to be a guide.

For example, the potential opportunities associated with adding solar capacity to large hydropower sites that can be flexibly operated is recognised (World Bank 2018), and is currently receiving attention in New Zealand (Maisch 2019). The modelled data for eleven potential sites are provided in Table 4, with a P90 uncertainty estimate of $\pm 4 \%$ to $\pm 8 \%$ (Solargis 2019c).

In terms of other economic opportunities, the Solar Atlas offers insight in terms of where, and how, solar can play an important role in the energy transition. For example, Anderson and Duke (2007), for the dairy industry, indicated that the solar resource in the Waikato region (above $1400 \mathrm{kWh} / \mathrm{m}^{2}$ from the Solar Atlas) is significantly higher than corresponding diary production regions in Germany (around $1150 \mathrm{kWh} / \mathrm{m}^{2}$ ), where thermal energy produced from solar is used for processing. Also, milk production and solar radiation exhibit a degree of correlation (Anderson and Duke 2007).

Investigations of how the solar resource of New Zealand is used, and can be used more effectively, to address energy demand profiles in the economy are ongoing.

\section{Note}

1. Light Detection And Ranging - a remote sensing technique that uses high-frequency laser pulses to gather information about a surface.

\section{Acknowledgements}

This work was supported by the University Research Fund of Victoria University of Wellington under Grant number 222568. 


\section{Disclosure statement}

No potential conflict of interest was reported by the author(s).

\section{Funding}

This work was supported by Victoria University of Wellington: [Grant Number URF grant number 222568].

\section{ORCID}

Alan C. Brent (DD http://orcid.org/0000-0003-3769-4512

James (Jim) Hinkley (iD http://orcid.org/0000-0002-4069-7362

Daniel Burmester (D) http://orcid.org/0000-0003-4032-685X

Ramesh Rayudu (D) http://orcid.org/0000-0001-9290-2447

\section{References}

Ahmad A, Anderson TN, Lie TT. 2015. Hourly global solar irradiation forecasting for New Zealand. Solar Energy. 122:1398-1408.

Anderson TN, Duke M. 2007. Solar energy use for energy savings in diary processing plants. IPENZ engineering treNZ. 2008-001. [accessed 2019 November 5]. https://researchcommons.waikato. ac.nz/handle/10289/3204.

Bódis K, Kougias J, Jäger-Waldau A, Taylor N, Szabó S. 2019. A high-resolution geospatial assessment of the rooftop solar photovoltaic potential in the European Union. Renewable and Sustainable Energy Reviews. 114:109309.

Bright JM. 2019. Solcast: Validation of a satellite-derived solar irradiance dataset. Solar Energy. 189:435-449.

Cebecauer T, Šúri M, Gueymard C. 2011. Uncertainty sources in satellite-derived Direct Normal Irradiance: How can prediction accuracy be improved globally? Proceedings of the SolarPACES Conference, Granada, Spain. [accessed 2019 November 5]. https://www. researchgate.net/profile/Chris_Gueymard/publication/228481494_Uncertainty_sources_in_sat ellite-derived_direct_normal_irradiance_how_can_prediction_accuracy_be_improved_globall y/links/0deec517ff684d35ec000000/Uncertainty-sources-in-satellite-derived-direct-normal-irra diance-how-can-prediction-accuracy-be-improved-globally.pdf.

Cebecauer T, Šúri M, Perez R. 2010. High performance MSG satellite model for operational solar energy applications. ASES National Solar Conference, Phoenix. [accessed 2019 November 5]. http://proceedings.ases.org/wp-content/uploads/2014/02/2010-086small.pdf.

Electricity Authority. 2019. Retail category / reports: installed distributed generation trends. Wellington: EA. [accessed 2019 October 23]. https://www.emi.ea.govt.nz/Retail/Reports/ Tagged/distributed-generation.

Eltayeb S. 2013. Renewable energy potential in New Zealand - by the numbers. Masters thesis. Manawatu: Massey University. [accessed 2019 November 4]. https://mro.massey.ac.nz/ bitstream/handle/10179/5211/02_whole.pdf.

Energy Sector Management Assistance Programme (ESMAP). 2019. Validation report: global solar Atlas 2.0 Validation report. Washington, DC: World Bank. [accessed 2020 March 24]. https:// solargis.com/docs/accuracy-and-comparisons/overview.

Hyett N. 2017. Basic measurements of radiation at station Lauder (2013-06). Melbourne: Bureau of Meteorology Research Centre. [accessed 2019 November 4]. https://doi.org/10.1594/PANGAEA. 877244 .

International Energy Agency. 2018. Key world energy statistics. Paris: IEA. [accessed 2019 October 23]. https://webstore.iea.org/key-world-energy-statistics-2018. 
International Energy Agency. 2019. Renewables. Paris: IEA. [accessed 2019 October 23]. https:// www.iea.org/renewables2019/.

International Finance Corporation. 2015. Utility-scale solar photovoltaic power plants: a project developer's guide. Washington DC: IFC. [accessed 2019 December 5]. https://www.ifc.org/ wps/wcm/connect/topics_ext_content/ifc_external_corporate_site/sustainability-at-ifc/publicati ons/publications_utility-scale+solar+photovoltaic+power+plants.

International Renewable Energy Agency. 2019. Solar energy. Abu Dhabi: IRENA. [accessed 2019 October 23]. https://irena.org/solar.

Kaskaoutis D, Polo J. 2019. Editorial for the special Issue "solar radiation, Modeling, and remote sensing". Remote Sensing. 11:1198.

Landcare Research. 2010. LENZ - mean annual solar radiation. Lincoln: Landcare Research. [accessed 2019 November 1]. https://ris.scinfo.org.nz/layer/48095-lenz-mean-annual-solarradiation/.

Leathwick J, Morgan F, Wilson G, Rutledge D, McLeod M, Johnstonn K. 2002. Land environments of New Zealand: a technical guide. Wellington: Ministry for the Environment. [accessed 2019 November 1]. https://lris.scinfo.org.nz/document/9290-lenz-technical-guide/.

Liley JB. 2013. Diffuse and direct components of solar radiation in ground-based and satellitederived data. radiation Processes in the atmosphere and Ocean (IRS2012). AIP Conf Proc. 1531:496-499.

Maisch M. 2019. New Zealand's largest solar farm to be built on water. pv magazine Australia. [accessed 2019 November 13]. https://www.pv-magazine.com/2019/09/04/new-zealandslargest-solar-farm-to-be-built-on-water/.

Mason IG, Page SC, Williamson AG. 2010. A 100\% renewable electricity generation system for New Zealand utilising hydro, wind, geothermal and biomass resources. Energy Policy. 38:3973-3984.

Ministry of Business, Innovation and Employment. 2019. Energy in New Zealand. Wellington: MBIE. [accessed 2019 October 23]. https://www.mbie.govt.nz/building-and-energy/energyand-natural-resources/energy-statistics-and-modelling/energy-publications-and-technical-pap ers/energy-in-new-zealand/.

NIWA. 2019a. The national climate database. Wellington: NIWA. [accessed 2019 November 1]. https://cliflo.niwa.co.nz.

NIWA. 2019b. Solarview version 1.0.0. Wellington: NIWA. [accessed 2019 November 1]. https:// solarview.niwa.co.nz.

NIWA. 2019c. Solarview help. Wellington: NIWA. [accessed 2019 December 13]. https://niwa.co. nz/our-services/online-services/solarview/help.

Parliamentary Counsel Office. 2019. Climate change response (zero carbon) Amendment Bill. Wellington: New Zealand Legislation. [accessed 2019 October 23]. https://www.parliament.nz/ en/pb/bills-and-laws/bills-proposed-laws/document/BILL_87861/climate-change-responsezero-carbon-amendment-bill.

Perez R, Cebecauer T, Śúri N. 2013. Semi-empirical satellite models. In: Kleissl J, editor. Solar energy forecasting and resource assessment. Boston: Academic Press; p. 21-28. [accessed 2019 November 5]. https://www.sciencedirect.com/science/article/pii/B9780123971777000024.

Philpott A, Read G, Batstone S, Miller A. 2019. The New Zealand electricity market: challenges of a renewable energy system. IEEE Power \& Energy Magazine. Jan/Feb:43-52. DOI: 10.1109/MPE. 2018.2871705.

Polo J, Perez R. 2019. Solar radiation modeling from satellite imagery. In: Polo J, Martín-Pomares L, Sanfilippo A, editor. Solar resource mapping - Fundamentals and applications. Green energy and technology. Zurich, Switzerland: Springer; p. 183-197. [accessed 2019 November 4]. https://link. springer.com/content/pdf/10.1007\%2F978-3-319-97484-2_6.pdf.

Refining NZ. 2019. Go ahead for solar farm. Whangarei: Refining NZ. [accessed 2019 November 13]. https://www.refiningnz.com/go-ahead-for-solar-farm/.

Solargis. 2019a. Global Solar Atlas 2.0. A free web-based application developed and operated by the company Solargis s.r.o. on behalf of the World Bank Group, utilizing Solargis data, with funding provided by the Energy Sector Management Assistance Program (ESMAP). [accessed 2019 November 5]. https://globalsolaratlas.info. 
Solargis. 2019b. Solar resource raster GIS data, New Zealand. Bratislava, Slovakia: Solargis s.r.o. Technical Report nr. 990-26/2019.

Solargis. 2019c. Validation and uncertainty of solar resource data. Bratislava, Slovakia: Solargis s.r.o. [accessed 2019 December 16]. https://solargis.com/docs/accuracy-and-comparisons/overview.

Suomalainen K, Wang V, Sharp B. 2017a. Rooftop solar potential based on LiDAR data: Bottom-up assessment at neighbourhood level. Renewable Energy. 111:463-475.

Suomalainen K, Wang V, Sharp B. 2017b. Auckland rooftop solar energy potential. Auckland: Energy Centre. [accessed 2019 November 4]. http://solarpower.cer.auckland.ac.nz.

Súri M, Cebecauer T. 2014. Satellite-based solar resource data: Model validation statistics versus user's uncertainty. ASES SOLAR 2014 Conference, San Francisco, USA. [accessed 2019 November 5]. https://solargis2-web-assets.s3.eu-west-1.amazonaws.com/public/publication/ 2014/1f0b376723/Suri-Cebecauer-ASES-Solar2014-Satellite-Based-Solar-Resource-Data-ModelValidation-Statistics-Versus-User-Uncertainty.pdf.

Š́ri M, Cebecauer T, Perez P. 2010. Quality procedures of Solargis for provision site-specific solar resource information. Proceedings of the SolarPACES Conference, Perpignan, France. [accessed 2019 November 5]. https://solargis2-web-assets.s3.eu-west-1.amazonaws.com/public/ publication/2010/77228ed51d/Suri-Cebecaue-Perez-SolarPACES2010-Quality-procedures-ofsolargis-for-provision-site-specific-solar-resource-information.pdf.

Transpower. 2018. Maps and geospatial data. Wellington: Transpower. [accessed 2019 November 5]. https://data-transpower.opendata.arcgis.com.

Transpower. 2019. The sun rises on a solar future. Wellington: Transpower. [accessed 2019 October 23]. https://www.transpower.co.nz/about-us/transmission-tomorrow/sun-rises-solar-energyfuture.

Western BE. 1990. The estimation of solar radiation in New Zealand. Solar Energy. 45:121-129.

World Bank. 2018. Where sun meets water: floating solar market report. Washington DC: World Bank. [accessed 2019 December 4]. http://www.esmap.org/sites/default/files/esmap-files/ ESMAP_FloatingSolar_Web_FINAL.PDF.

World Climate Research Programme (WCRP). 2018. 15th baseline surface radiation network (BSRDN) scientific review and workshop. Boulder: WCRP. [accessed 2019 November 4]. https://www.wcrp-climate.org/resources/wcrp-publications/1272-pub-2018. 